\title{
Growth Environment and Leaf Anatomy Affect Nondestructive Estimates of Chlorophyll and Nitrogen in Citrus sp. Leaves
}

\author{
John L. Jifon' ${ }^{1}$ \\ Texas A\&M University, TAES, 2415 E. Highway 83, Weslaco, TX 78596 \\ James P. Syvertsen and Eric Whaley \\ University of Florida, IFAS, Citrus Research and Education Center, 700 Experiment Station Road, \\ Lake Alfred, FL 33850
}

\begin{abstract}
AdDitional INDEX words. SPAD-502, Observer, CCM-200, leaf dry weight per unit area
Aвstract. Correlations between extractable leaf chlorophyll $(\mathrm{Chl})$ concentration and portable, nondestructive leaf "greenness" meter readings imply that such estimates can be used as surrogate measurements of leaf nitrogen (N) status. However, few studies have actually found a direct relationship between Chl meter readings and leaf $\mathrm{N}$. We evaluated the utility of two handheld transmittance-based Chl content meters (SPAD-502, Minolta Corp. and CCM-200, OptiSciences) and one reflectance-based meter (Observer, Spectrum Technologies), in estimating Chl and N concentrations in intact leaves of several citrus cultivars. Total Chl determined analytically, correlated well with nondestructive Chl meter readings $\left(r^{2}: 0.72\right.$ to $\left.0.97 ; P<0.0001\right)$, but regression models differed among cultivars using the same meter and also among meters for a given cultivar. The relationships were generally more linear and stronger at low Chl concentrations $\left(<0.5 \mathrm{mmol} \cdot \mathrm{m}^{-2}\right)$ than at higher $\mathrm{Chl}$ concentrations, reflecting increased variability in Chl meter readings with increasing leaf $\mathrm{Chl}$. Significant relationships between $\mathrm{Chl}$ meter readings and measured leaf $\mathrm{N}$ concentrations were also found in all the cultivars tested $\left(r^{2}: 0.23\right.$ to $\left.0.69 ; P<0.01\right)$, but the data were more variable than those for $\mathrm{Chl}$. Field-grown leaves were significantly thicker and had higher $\mathrm{Chl}$ meter readings than greenhouse-grown leaves of similar Chl or $\mathrm{N}$ concentrations. The results suggest that nondestructive $\mathrm{Chl}$ content meters can overestimate $\mathrm{Chl}$ and $\mathrm{N}$ in thicker leaves and/or leaves with high $\mathrm{Chl}$ concentrations. A single prediction equation derived from a wide range of $\mathrm{Chl}$ or $\mathrm{N}$ concentrations could be applicable across the range of citrus cultivars when grown in the same environment. Potential limitations associated with leaf thickness as influenced by environmental factors may necessitate the development of more specific calibration equations.
\end{abstract}

Nitrogen is the major nutrient element that most frequently limits the growth and productivity of nonleguminous plants (Below, 1995). Leaf $\mathrm{N}$ concentration can range from $2 \%$ to $6 \%$ of dry weight (Jones, 1998; Munson 1998) and is usually strongly correlated with photosynthetic capacity and yield (Evans, 1989). Dark green leaves, high photosynthetic activity, and vigorous vegetative growth are characteristics of plants with adequate $\mathrm{N}$ supply. Conversely, inadequate $\mathrm{N}$ supply can lead to chlorosis and stunted growth. Efficient management of fertilizer $\mathrm{N}$ to achieve optimum productivity while preserving the quality of the environment is an important objective in modern agricultural systems. Theoretically, effective $\mathrm{N}$ management requires frequent plant and soil monitoring to ensure that neither too little nor too much fertilizer $\mathrm{N}$ is applied. The standard methods for determining plant $\mathrm{N}$ status (extraction and spectrophotometric determination) are destructive and time-consuming (Munson, 1998).

Since leaf $\mathrm{N}$ content is often highly correlated with leaf chlorophyll (Chl) concentration (Syvertsen, 1987), noninvasive, portable

Received for publication 3 Mar. 2003. Accepted for publication 8 Sept. 2004. This research was partially supported by grants from US/IS BARD and Spectrum Technologies Inc. and was funded by the Florida Agricultural Experiment Station. Approved for publication as Journal Series No. R-10091. Special thanks to Spectrum Technologies Inc. for loan of the Observer prototype and the Minolta SPAD-502 meters and to Dan Harkins of Opti-Sciences, Inc. for the loan of the CCM-200 prototype meter. The assistance of Jill Dunlop (CREC) is gratefully acknowledged.

${ }^{1}$ Corresponding author: e-mail:jljifon@agprg.tamu.edu; phone:(956) 968-5585; fax:(956) 969-5620 optical devices based on principles of light transmittance or reflectance from an intact leaf have been developed to estimate leaf greenness and $\mathrm{Chl}$. Such readings are thought to serve as indirect measures of leaf N status (Schepers et al., 1998; Whaley, 2001). Leaf chlorophyll meters are calibrated to measure the interaction of thylakoid Chl with incident light, and numerous studies have generally shown good correlations between extractable $\mathrm{Chl}$ and nondestructive chlorophyll meter readings, although specific calibration for different species and environmental conditions is always highly recommended (Cate and Perkins, 2003; Monje and Bugbee, 1992; Neilsen et al., 1995; Richardson et al., 2002; Schaper and Chacko, 1991). However, leaf greenness readings do not always translate directly into strong correlations between leaf $\mathrm{N}$ and photosynthetic activity. This may be due to the pattern of allocation of leaf $\mathrm{N}$ between soluble proteins (of which Calvin Cycle components account for a large proportion) and the pigment-protein/reaction center complexes of thylakoids (of which light absorption by chlorophyll depends), which vary with N supply and canopy light environment (Evans, 1989; Evans and Poorter, 2001). Leaf thickness and leaf dry weight per unit area are often strongly correlated as both vary with environmental conditions during leaf expansion (Syvertsen et al., 1995), and both characteristics can acclimate to changing light environments even after full leaf expansion in perennial citrus leaves (Syvertsen and Smith, 1984).

Direct relationships between leaf greenness meter readings and leaf $\mathrm{N}$ content have been evaluated in annual crops, such as corn (Zea mays L.) (Bullock and Anderson 1998), cotton (Gossypium hirsutum L.) (Wood et al., 1992), potato (Solanum tuberosum 
L.) (Minotti et al., 1994), and rice (Oryza sativa L.) (Turner and Jund, 1991). Few studies have evaluated such relationships for woody plant species such as Citrus that have relatively thick and long-lived leaves. Reliable correlations between chlorophyll meter readings and extractable leaf $\mathrm{N}$ content could become a valuable tool for fertilizer $\mathrm{N}$ management.

The objective of this study was to characterize cultivar effects and the influence of leaf thickness on the relationships between chlorophyll meter indices, extractable $\mathrm{Chl}$, and $\mathrm{N}$ concentration in citrus leaves. A wide range of leaf $\mathrm{N}, \mathrm{Chl}$, and chlorophyll meter readings were obtained by sampling young and mature leaves from several citrus cultivars that had been grown under different environmental conditions.

\section{Materials and Methods}

Plant material. This study was conducted at the Univ. of Florida's Citrus Research and Education Center, Lake Alfred (lat. $28.09^{\circ} \mathrm{N}$, long. $81.37^{\circ} \mathrm{W}$, elevation $51 \mathrm{~m}$ above mean sea level). The cultivars sampled were 'Hamlin' orange (Citrus sinensis L.), 'Redblush' grapefruit (C. paradisi Macf.), 'Valencia' orange $(C$. sinensis), 'Smooth Flat Seville' (SFS) (C. aurantium L. hybrid), 'Volkamer' lemon (Volk) (C. volkameriana Ten. \& Pasq.), and 'Temple' orange $(C$. reticulata Blanco $\times C$. sinensis $)$. The 'Valencia' and 'Redblush' trees were field-grown (10-15 years old) and were part of an $\mathrm{N}$ fertilizer rate study using four annual application rates at $0,150,250$, and $350 \mathrm{~kg} \cdot \mathrm{ha}^{-1}$ of $\mathrm{N}$. The rest of the trees were $2-4$ years old, either grown outdoors in $10-\mathrm{L}$ plastic containers or in a greenhouse in 3 -L pots. The containerized plants received $\approx 0.5 \mathrm{~kg} /$ tree per year of $\mathrm{N}$ using a complete $(\mathrm{N}-\mathrm{P}-\mathrm{K})$ water-soluble fertilizer (Peter's Corp, St. Louis). 'Hamlin' leaves were also sampled from field-grown trees in commercial orchards that received $\approx 150 \mathrm{~kg} \cdot \mathrm{ha}^{-1}$ per year of $\mathrm{N}$.

ChlOROPHYLl CONTENT METERS. Three commercially available hand-held chlorophyll meters were evaluated: soil-plant analysis development meter (SPAD-502; Minolta Corp., Ramsey, N.J.), chlorophyll content meter (CCM-200; Opti-Sciences, Tyngsboro, Mass.), and Observer (currently sold as Field Scout CM-1000 chlorophyll meter; Spectrum Technologies, Plainfield, Ill.). Measurements with the SPAD-502 and CCM-200 units are based on the ratio of chlorophyll absorbance in two wavebands (red, $650 \mathrm{~nm}$, peak chlorophyll absorbance, and infrared, $\approx 940$ $\mathrm{nm}$, nonchlorophyll absorbance). The Observer estimates of $\mathrm{Chl}$ are based on ratios of the amount of ambient and reflected light at 700 and $840 \mathrm{~nm}$ (Whaley, 2001). All instruments were calibrated before use following procedures recommended by their manufacturers.

Procedures. Leaves used for all measurements $(n=3-5)$ were randomly sampled from the current-year's flush ( 3 to 5 months old) and around exterior canopy positions of four to six trees per cultivar. For each leaf, the average of four to six readings in areas that did not overlap (two to three on each side of the midrib) was recorded using each of the three instruments. For Observer measurements, the adaxial surface of the target leaf was held perpendicular to the sun's rays to maximize light reflectance from the leaf surface into the instrument's detector. The sun was always behind the user with the line between the leaf surface and the instrument detector almost parallel to the sun's rays. Extraneous reflectance of $840 \mathrm{~nm}$ light into the instrument was minimized by holding the detector close to the leaf $(\approx 0.3 \mathrm{~m}$ distance) without blocking the sun's rays. All measurements were conducted under natural light conditions (photosynthetic photon flux $\approx 1300 \mu \mathrm{mol} \cdot \mathrm{m}^{-2} \cdot \mathrm{s}^{-1}$ in the field, and $\approx 600 \mu \mathrm{mol} \cdot \mathrm{m}^{-2} \cdot \mathrm{s}^{-1}$ in the greenhouse). Immediately following chlorophyll meter readings, four leaf disks $\left(1.1 \mathrm{~cm}^{2}\right.$ each) were sampled with a cork borer from the mid lamina area of each leaf at the same approximate positions as the nondestructive measurements. These disks were used for $\mathrm{Chl}$ and leaf dry weight per unit area $\left[\mathrm{LDW} / \mathrm{A}\left(\mathrm{g} \cdot \mathrm{m}^{-2}\right)\right]$ analyses. Chl was extracted from two leaf disks with $N, N$-Dimethylformamide and quantified with the equations of Wellburn (1994) after recording absorbance at 647 and $664 \mathrm{~nm}$ with a spectrophotometer (model UV2401P; Shimadzu, Columbia, Md.). LDW/A was determined from the other two leaf disks after drying to constant weight. Leaf $\mathrm{N}$ was determined on the remaining leaf tissue using an NA1500 C-N analyzer (Fisson Institute, Dearborn, Mich.). Due to limitations on sample size/number, leaf $\mathrm{N}$ analyses were conducted on only four of the six cultivars studied. When the remaining tissue from a single leaf was inadequate for $\mathrm{N}$ analysis, several leaf tissues from the same plant were pooled.

DATA ANALYSIS. For each cultivar, regression equations relating chlorophyll meter readings and measured $\mathrm{Chl}$ or $\mathrm{N}$ were obtained. Differences in the regression parameters (slopes and intercepts) among cultivars using the same $\mathrm{Chl}$ meter and among $\mathrm{Chl}$ meters for a given cultivar were further evaluated using the mixed model procedures of SAS after performing angular (arcsine) transformations of the data (Littell et al., 1996).

\section{Results}

The range of measured $\mathrm{Chl}$ concentrations varied among the cultivars investigated depending upon leaf age, cultural treatments (e.g., N supply), and growth environment. Some cultivars (e.g., 'Hamlin', 'Redblush', and 'Valencia') had a wide range of measured leaf $\mathrm{Chl}$ concentrations $\left(\approx 0.05-0.72 \mathrm{mmol} \cdot \mathrm{m}^{-2}\right)$, whereas others (e.g., 'Smooth Flat Seville', 'Temple', and 'Volk') had a narrower range (generally $<0.5 \mathrm{mmol} \cdot \mathrm{m}^{-2}$ ). Young leaves on 'Temple' trees grown in the greenhouse had the narrowest Chl range $\left(0.03-0.13 \mathrm{mmol} \cdot \mathrm{m}^{-2}\right)$, whereas recently matured leaves on field-grown 'Valencia' trees had a wider range of $\mathrm{Chl}$ concentrations (0.05-0.72 $\mathrm{mmol} \cdot \mathrm{m}^{-2}$; Fig. 1).

Strong positive correlations between $\mathrm{Chl}$ meter readings and measured Chl were found for all cultivars $(P<0.0001$; Fig. 1). The relationships were generally more linear and less variable at lower $\left(<0.5 \mathrm{mmol} \cdot \mathrm{m}^{-2}\right)$ than at higher $\mathrm{Chl}$ concentrations. For leaves with Chl concentrations $>0.5 \mathrm{mmol} \cdot \mathrm{m}^{-2}$, it was not possible to obtain nondestructive $\mathrm{Chl}$ estimates using the CCM200 meter due to the apparently low sensitivity of the prototype CCM-200 unit used in this study. Therefore, using the same leaves and plants as those used for SPAD-502 and Observer readings, the only CCM-200 readings obtained were on leaves with Chl concentrations $<0.5 \mathrm{mmol} \cdot \mathrm{m}^{-2}$ (Fig. 1).

Slopes of the regression models differed among cultivars for measurements with the same chlorophyll meter $(P<0.0001)$, and also among Chl content meters for measurements on leaves of a given cultivar $(P<0.0001)$. The relationships obtained with the CCM-200 and Observer meters were generally linear, whereas those obtained with the SPAD-502 meter were either linear (for cultivars with a narrow $\mathrm{Chl}$ concentration range) or quadratic (for cultivars with wider ranges of extractable leaf Chl). Coefficients of determination $\left(r^{2}\right)$ for leaf Chl estimates were consistently highest with the SPAD-502 meter $\left(r^{2}>0.90\right)$ compared to those obtained with the CCM-200 and Observer meters (Fig. 1).

Measured leaf $\mathrm{N}$ concentrations ranged from 0.4 to $3.9 \mathrm{~g} \cdot \mathrm{m}^{-2}$ 


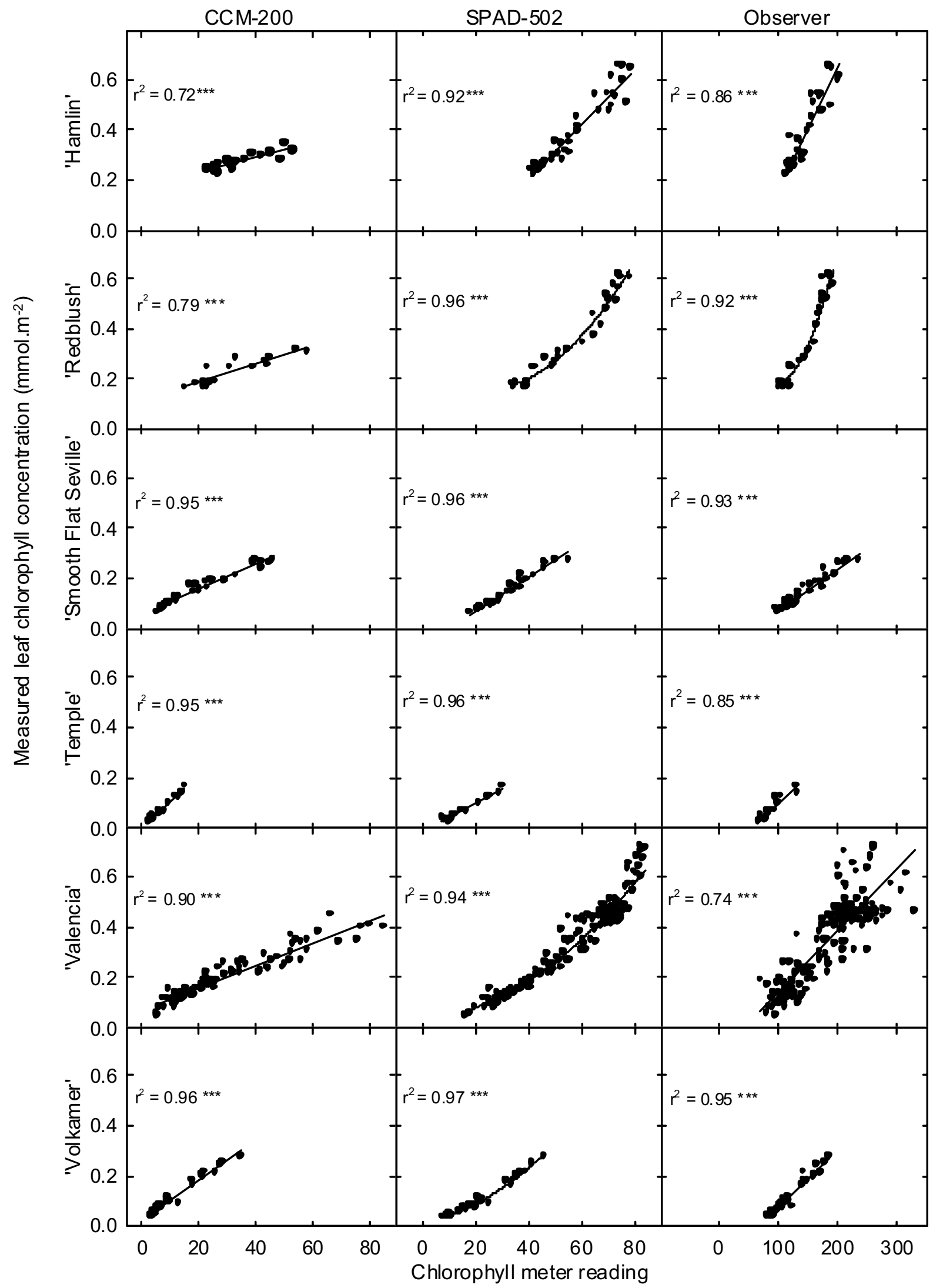

Fig. 1. The relationships between nondestructive leaf chlorophyll meter readings and measured chlorophyll concentrations in citrus leaves. The chlorophyll meter readings were obtained with two transmittance-based chlorophyll content meters (SPAD-502 chlorophyll meter, Minolta Corp., and CCM-200, Opti-Sciences) and a reflectance-based meter (Observer, Spectrum Technologies). Statistical significance: $r^{2}=$ adjusted coefficient of determination; NS $=$ nonsignificant $(P>$ $0.05) ; * P<0.05 ; * * P<0.01 ; * * * P<0.001$. 


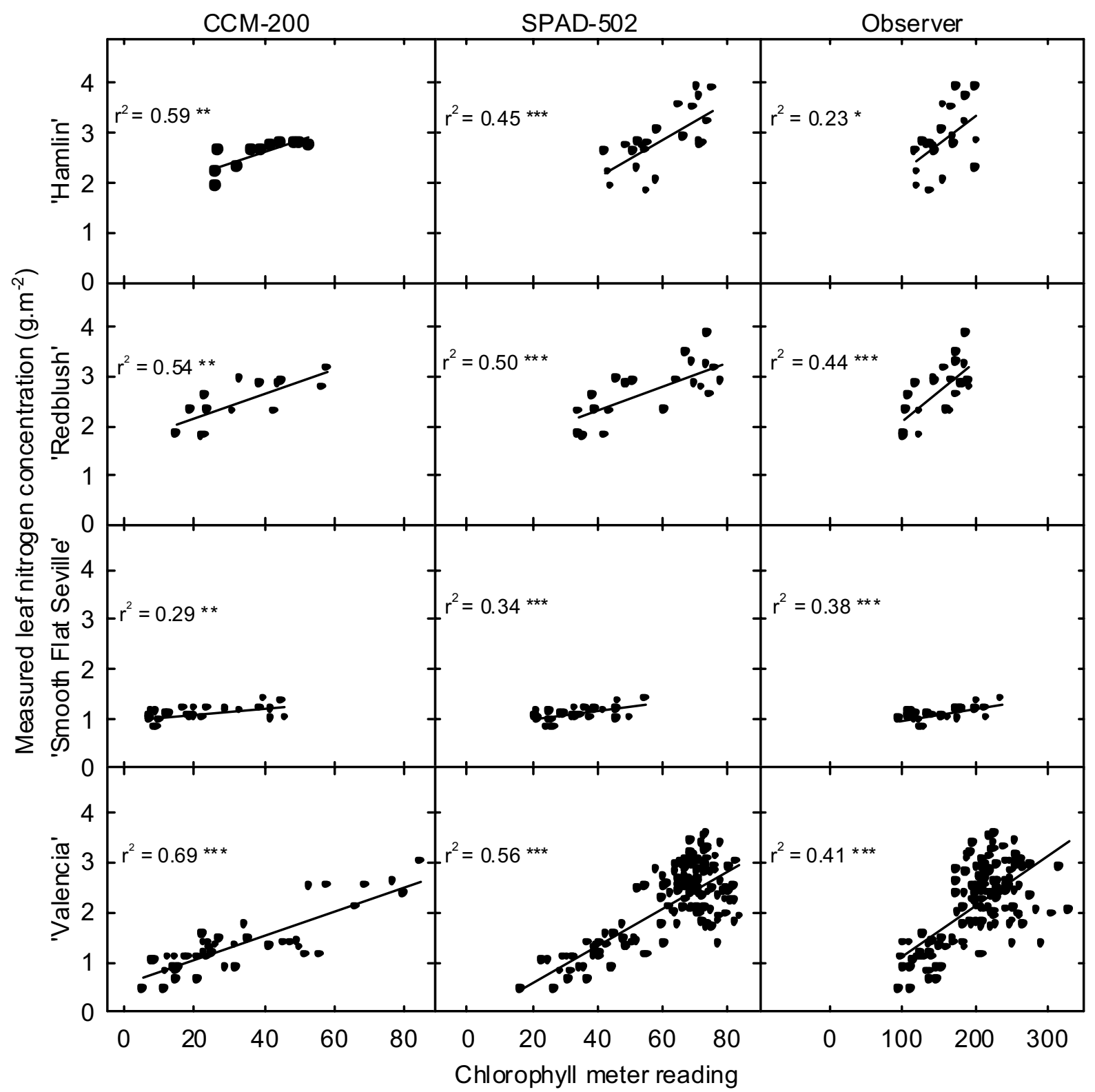

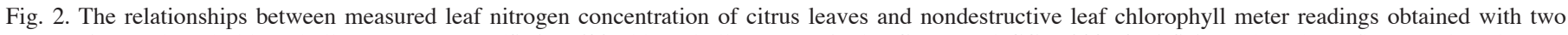

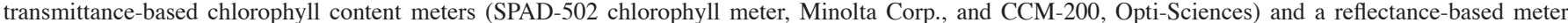

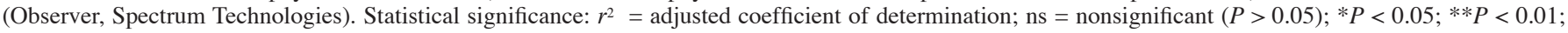
$* * * P<0.001$

( $\approx 0.7 \%$ to $4.1 \%$ dry weight) across the cultivars evaluated (Fig. 2 ) and were positively correlated with instrument readings for all cultivars $(P<0.01)$. The $r^{2}$ values for the $\mathrm{N}$ relationships obtained with the CCM-200 (0.30-0.69) were either similar to or greater than those obtained with the SPAD-502 (0.34-0.56) and Observer (0.23-0.44). Similar to the limitations with the Chl relationships, the only readings obtained with the CCM-200 were on leaves with $\mathrm{N}$ concentrations $<3 \mathrm{~g} \cdot \mathrm{m}^{-2}$. Slopes of the regression models also differed among cultivars for measurements with the same chlorophyll meter $(P<0.001)$.

When data were pooled across cultivars, significant positive relationships between $\mathrm{Chl}$ meter readings and leaf $\mathrm{Chl}$ were obtained with all meters (Fig. 3, $P<0.0001$ ). The $r^{2}$ values for pooled Chl data were 0.89, 0.93, and 0.67 for the CCM-200, SPAD-502, and Observer meters, respectively. Relationships for pooled leaf $\mathrm{N}$ were also significant $(P<0.011)$ and $r^{2}$ values were $0.41,0.54$, and 0.21 for the CCM-200, SPAD-502, and Observer meters, respectively (data not shown).

Measured LDW/A varied strongly with growth environment, leaf $\mathrm{Chl}$ and $\mathrm{N}$ concentrations (Fig. 4). Leaves of field-grown plants had higher LDW/A than those of greenhouse-grown plants at a given $\mathrm{N}$ or Chl concentration (Fig. 4). Within a given growth environment, LDW/A was positively correlated with leaf $\mathrm{N}$ and Chl. This growth environment effect on LDW/A was reflected in the relationships between $\mathrm{Chl}$ or $\mathrm{N}$ and $\mathrm{Chl}$ meter readings as illustrated by data for 'Hamlin' leaves collected from two field sites and from a greenhouse (Fig. 5). For a given leaf Chl concentration, Chl meter readings were generally higher in leaves of field-grown plants than in leaves of greenhouse-grown plants. Adjustment of instrument readings for LDW/A did not eliminate the growth environment effect on the relationships between $\mathrm{Chl}$ meter readings and extracted Chl (data not shown). 


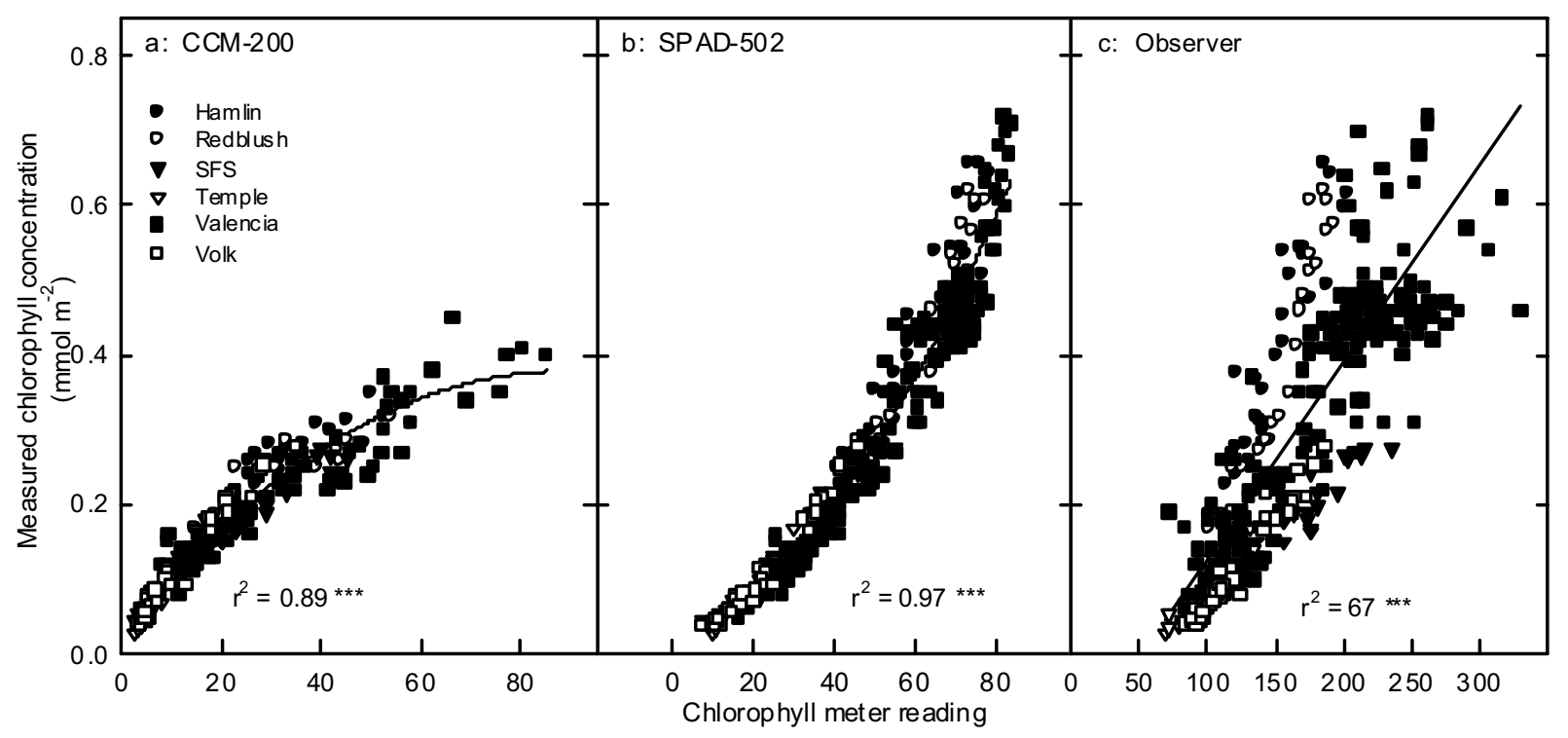

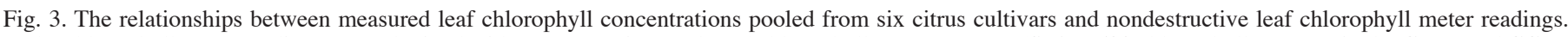

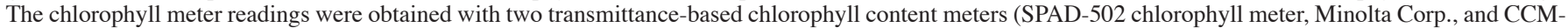

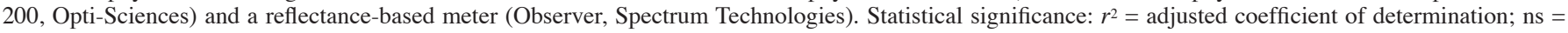
nonsignificant $(P>0.05)$; $* P<0.05$; ** $P<0.01$; *** $P<0.001$.

\section{Discussion}

The three hand-held Chl meters evaluated yielded different calibration equations for each cultivar. The SPAD-502 meter readings consistently had the highest correlations with leaf $\mathrm{Chl}$ and the least variability compared to the other transmittance-based meter, the CCM-200 and to the reflectance-based meter, Observer. The difficulty in obtaining nondestructive estimates of $\mathrm{Chl}$ with the CCM-200 at high leaf Chl concentrations $\left(>0.5 \mathrm{mmol} \cdot \mathrm{m}^{-2}\right)$ limited its range of use and probably contributed to differences in regression slopes compared to the SPAD-502. The CCM-200 meter used in our study was a prototype instrument that uses differential transmission at 940 and $665 \mathrm{~nm}$. The production model of the CCM-200 uses a shorter wavelength $(\approx 655 \mathrm{~nm})$ with improved sensitivity (D. Harkins, personal communication).

For the reflectance-based Observer, linear models adequately represented the relationship between leaf $\mathrm{Chl}$ and instrument readings but the goodness-of-fit was generally lower compared to SPAD-502. Variations in light transmission through the leaf and in leaf surface reflectivity effects caused by incident irradiance, may explain the variability in readings obtained with the Observer. In experiments using field-grown cotton, placement of a black, absorptive background behind the leaf while taking measurements helped minimize extraneous reflectance of $840 \mathrm{~nm}$ light and to a lesser extent, reflectance of $700 \mathrm{~nm}$ light (Read et al., 2003). Use of the dark background lowered instrument-calculated indices and, although not verified, potentially improved accuracy in Chl estimation (Read et al., 2003). In the present study, the most reliable and reproducible readings from the Observer were obtained when the target leaf surface and the instrument's ambient light sensors were held nearly perpendicular to the sun's rays.

For cultivars with a relatively wide range of measured $\mathrm{Chl}$ concentrations (e.g., 'Redblush' and 'Valencia'), the relationships obtained with SPAD-502 were better described by quadratic equations (generally higher $r^{2}$ values) than linear models. Similar results have also been demonstrated in previous studies especially when a wide range of leaf $\mathrm{Chl}$ was available (Ichie et al., 2002;
Monje and Bugbee, 1992; Richardson et al., 2002; Schaper and Chacko, 1991). The nonlinear response indicates a reduction in the efficiency of light absorption by leaves with high Chl contents due perhaps to sieve effects and to chloroplast rearrangement in response to the radiation environment (Taiz and Zeiger, 1991; Terashima and Saeki, 1983; Vogelmann, 1989). Relationships obtained with the CCM-200 (using the same leaves and plants as those used for SPAD-502 and Observer readings) were better described by linear models because its range of detection $(0-0.5$ $\mathrm{mmol} \cdot \mathrm{m}^{-2}$ ) fell within the linear phase of the seemingly curvilinear relationship between measured leaf $\mathrm{Chl}$ and transmittance-based $\mathrm{Chl}$ meter readings. For the reflectance-based Observer meter, relationships between $\mathrm{Chl}$ meter readings and measured leaf $\mathrm{Chl}$ were generally linear.

The relationships between $\mathrm{Chl}$ meter readings and leaf $\mathrm{N}$ were not as strong as those with leaf Chl. A possible reason for this disparity is that for most species, and notwithstanding the widely observed strong correlation between leaf $\mathrm{Chl}$ and $\mathrm{N}$, more leaf $\mathrm{N}$ is generally allocated to the soluble protein pool than to pigment-protein/reaction center complexes (Evans, 1989). The nondestructive estimates of $\mathrm{Chl}$ however, only represent the thylakoid fraction of total leaf $\mathrm{N}$. A majority of the relationships between leaf $\mathrm{N}$ and instrument readings were nonetheless significant indicating that with proper calibration, readings from these meters can be used as an indicator of citrus leaf $\mathrm{N}$.

The disproportionate allocation of $\mathrm{N}$ between soluble proteins and light harvesting complexes can be exacerbated by leaf age, growth environment, or cultural practices, such as N supply (Bondada and Syvertsen, 2003; Evans and Poorter, 2001; Syvertsen and Smith, 1984). These factors could explain the disparity in chlorophyll meter readings for leaves of the same $\mathrm{N}$ content grown in different environments (Fig. 4). Light absorption/transmission and chlorophyll meter readings were probably influenced by leaf physical characteristics resulting from growth in different environments (Syvertsen et al., 1995). Field-grown leaves were typically very thick with LDW/A values $\left(80-115 \mathrm{~g} \cdot \mathrm{m}^{-2}\right)$ significantly greater than those of greenhouse-grown leaves $\left(50-95 \mathrm{~g} \cdot \mathrm{m}^{-2} ; \mathrm{Fig}\right.$. 


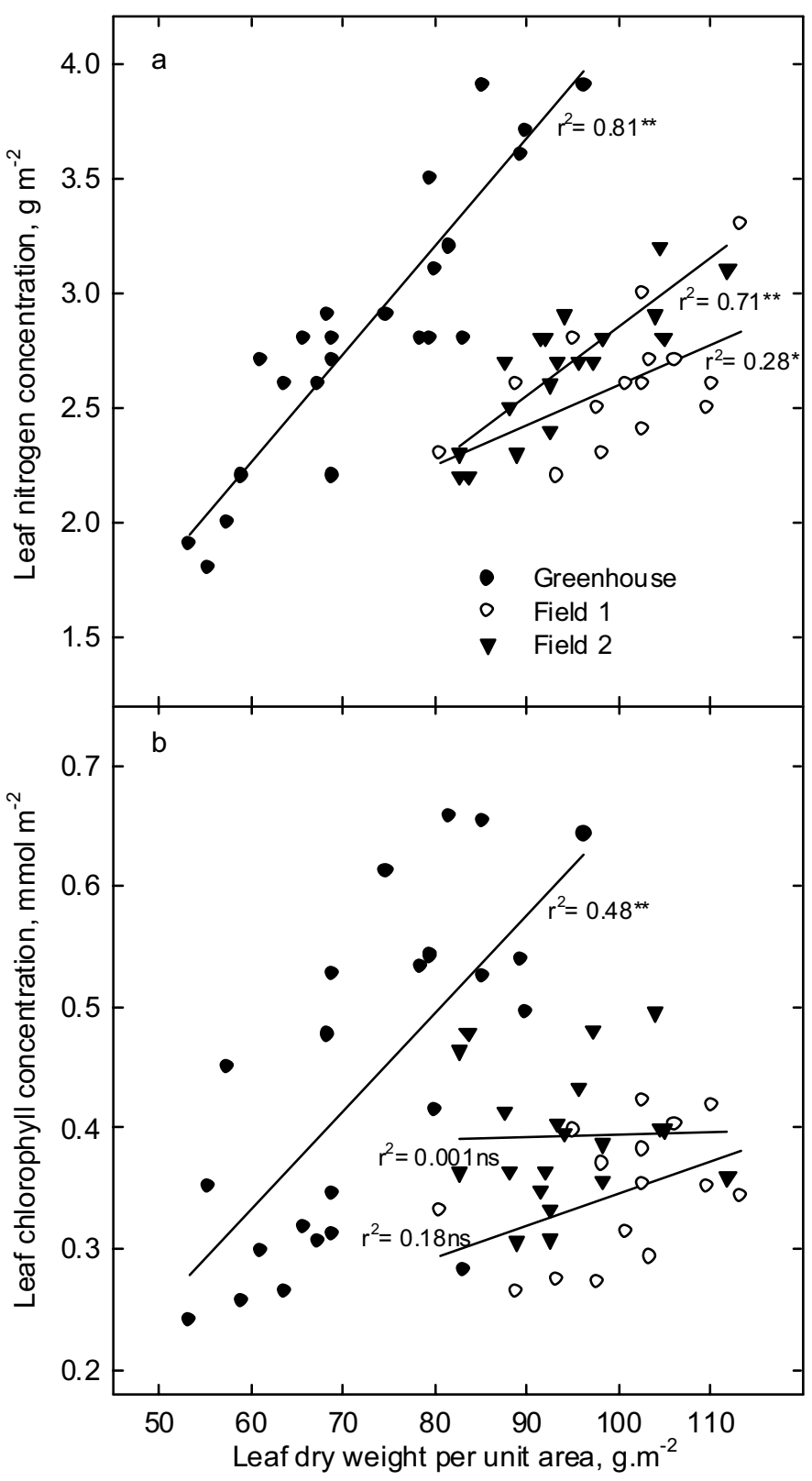

Fig. 4. The influence of growth environment (field or greenhouse) on the relationships between measured leaf nitrogen (a) or chlorophyll (b) concentrations and leaf dry weight per unit area [LDW/A $\left.\left(\mathrm{g} \cdot \mathrm{m}^{-2}\right)\right]$ in leaves of 'Hamlin' orange (Citrus sinensis L.). Statistical significance: $r^{2}=$ adjusted coefficient of determination; $\mathrm{ns}=$ nonsignificant $(P>0.05) ; * P<0.05 ; * * P<$ $0.01 ; * * * P<0.001$

4). This growth environment effect was clearly demonstrated by comparing $\mathrm{Chl}$ and $\mathrm{N}$ data of 'Hamlin' grown under greenhouse and field conditions (Fig. 5). Under high irradiances, chloroplast rearrangement within leaf cells can influence the amount of light absorbed by the leaf (Taiz and Zeiger, 1991) and hence, Chl meter readings. Acclimation to high-light environments is generally characterized by increased allocation of leaf organic $\mathrm{N}$ to soluble proteins (Evans and Poorter, 2001) and increased leaf thickness with high LDW/A due in part to extra layers of palisade or longer palisade cells (Bondada and Syvertsen, 2003; Taiz and Zeiger, 1991). High LDW/A can diminish light transmittance by increasing light scattering and optical path length through the leaf (Terashima and Saeki, 1983; Vogelmann, 1989). In the present study, adjusting the instrument readings for LDW/A as was suggested for rice (Peng et al., 1993) did not eliminate the growth environment effect. The effects of light scattering may be reduced by using instruments equipped with collimating lenses, large detector areas compared to the area of the light source, and by placing the detector as close as possible to the target leaf (Hardacre and Nicholson, 1984; Monje and Bugbee, 1992). Changes in LDW/A associated with leaf age may also account for some of the variability in the nondestructive estimates of Chl or N. For example, Nielsen et al. (1995) found that correlations between $\mathrm{Chl}$ meter readings and $\mathrm{Chl}$ concentration of apple leaves were stronger at the beginning of the growing season than at harvest.

A major limitation of nondestructive $\mathrm{Chl} / \mathrm{N}$ estimation is that a single prediction equation cannot be applied across a wide range of cultivars. Although our data suggest that this could be possible for the citrus cultivars evaluated (Fig. 3), potential limitations associated with leaf anatomy (LDW/A) as influenced by growing conditions, may dictate that specific calibration equations be derived for specific circumstances. Standardized sampling procedures will reduce within-tree variability and improve the accuracy of the derived estimates. Thus, it is recommended that leaves be sampled periodically and new calibration equations derived. Additional precautions such as avoiding major veins when taking readings or in the case of the Observer meter, using a black background and maintaining a proper leaf angle with respect to incident radiation, could improve the predictive utility of these meters.

\section{Literature Cited}

Below, F.E. 1995. Nitrogen metabolism and crop productivity. In: M. Pessarakli (ed.). Handbook of plant and crop physiology, p. 275-301. Marcel Dekker, New York.

Bondada, B.R. and J.P. Syvertsen. 2003. Leaf chlorophyll, net gas exchange and chloroplast ultrastructure in citrus leaves of different nitrogen status. Tree Physiol. 23:553-559.

Bullock, D.G. and D.S. Anderson. 1998. Evaluation of the Minolta SPAD-502 chlorophyll meter for nitrogen management in corn. J. Plant Nutr. 21:741-755.

Cate, T.M. and T.D. Perkins. 2003. Chlorophyll content monitoring in sugar maple (Acer saccharum). Tree Physiol. 23:1077-1079.

Evans, J.R. 1989. Photosynthesis and nitrogen relationships in leaves of $\mathrm{C}_{3}$ plants. Oecologia 78:9-19.

Evans, J.R. and H. Poorter. 2001. Photosynthetic acclimation of plants to growth irradiance: the relative importance of specific leaf area and nitrogen partitioning in maximizing carbon gain. Plant Cell Environ. 24:755-767.

Hardacre, A.K. and H.F. Nicholson. 1984. A portable photometer for the measurement of chlorophyll in intact leaves. N.Z. J. Expt. Agr. 12:357-362.

Ichie, T., Y. Kitahashi, S. Matsuki, Y. Maruyama, and T. Koike. 2002. The use of a portable nondestructive type nitrogen meter for leaves of woody plants in field studies. Photosynthetica 40:289-292.

Jones, J.B., Jr. 1998. Plant nutrition manual. CRC Press, Boca Raton, Fla.

Littell, R.C., G.A. Milliken, W.W. Stroup, and R.C. Wolfinger. 1996. SAS system for mixed models. SAS Inst., Cary, N.C.

Minotti, P.L., D.E. Halseth, and J.B. Sieczka. 1994. Field chlorophyll measurements to assess the nitrogen status of potato varieties. HortScience 29:1497-1500.

Monje, O.A. and B. Bugbee. 1992. Inherent limitations of nondestructive chlorophyll meters: A comparison of two types of meters. HortScience 27:69-71.

Munson, R.D. 1998. Principles of plant analysis, p. 1-25. In: Y.P. Kalra (ed.). Handbook of reference methods for plant analysis. CRC Press, Boca Raton, Fla. 


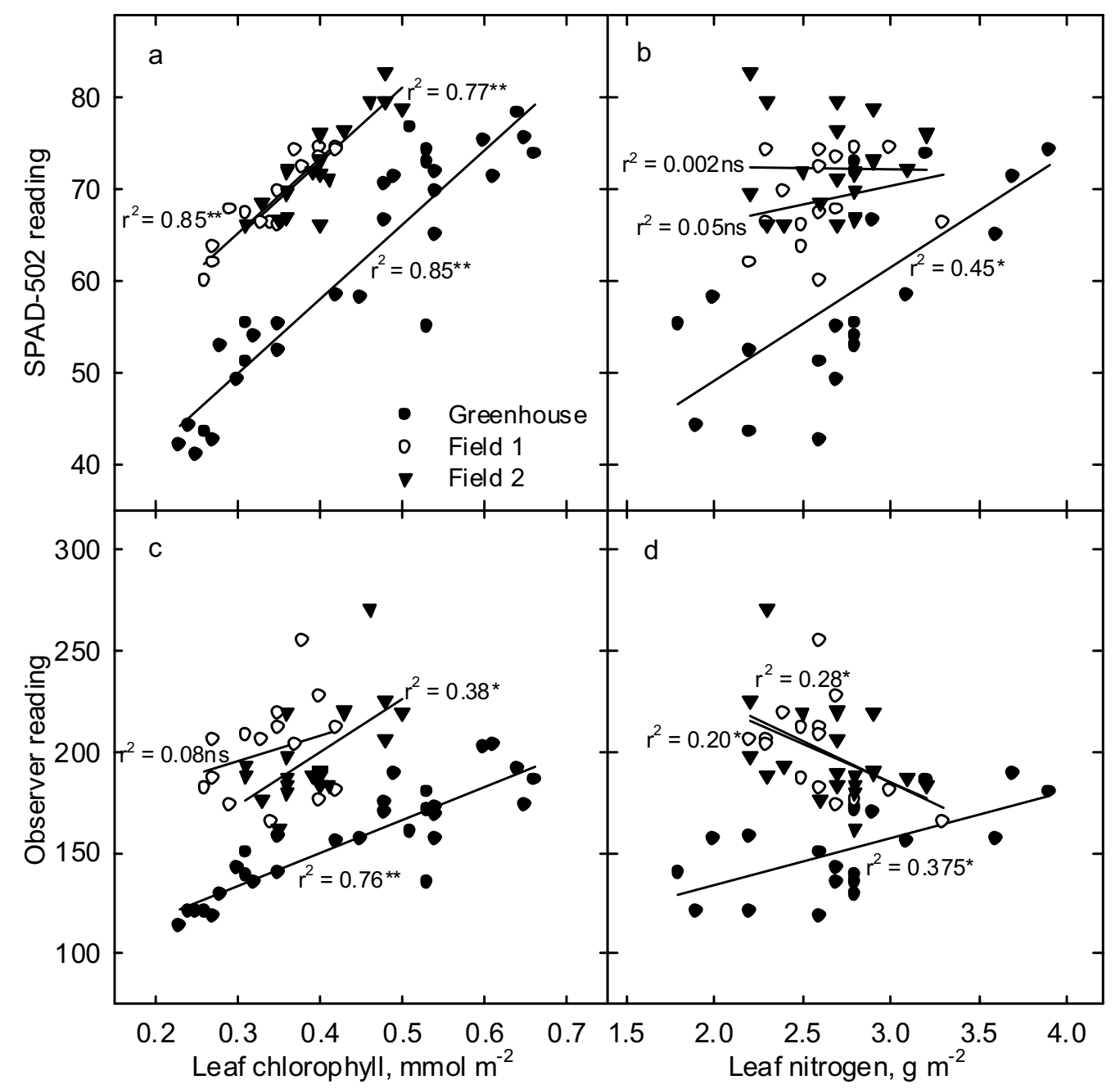

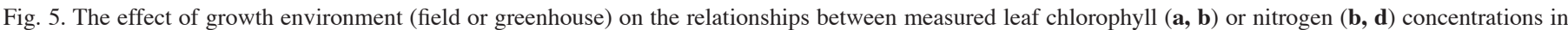

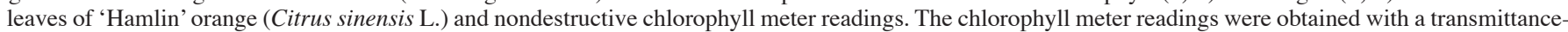
based meter (SPAD-502 chlorophyll meter, Minolta Corp.) and a reflectance-based meter (Observer, Spectrum Technologies). Statistical significance: $r^{2}=$ adjusted coefficient of determination; ns $=$ nonsignificant $(P>0.05) ; * P<0.05 ; * * P<0.01 ; * * * P<0.001$.

Neilsen, D., E.J. Hogue, G.H. Nielsen, and P. Pachomchuk. 1995. Using SPAD-502 values to assess the nitrogen status of apple trees. HortScience 30:508-512.

Peng, S., F.V. Garcia, R.C. Laza, and K.G. Cassman. 1993. Adjustment for specific leaf weight improves chlorophyll meter's estimate of rice leaf nitrogen concentration. Agron. J. 85:987-990.

Read, J.J., E.L. Whaley, L. Tarpley, and K.R. Reddy. 2003. Digital imaging and spectral techniques: Applications to precision agriculture and crop physiology. ASA Spec. Publ. no. 66. p. 177-195.

Richardson, A.D., S.P. Duigan, and G.P. Berlyn. 2002. An evaluation of noninvasive methods to estimate foliar chlorophyll content. New Phytol. 153:185-194.

Schaper, H. and E.K. Chacko. 1991. Relation between extractable chlorophyll and portable chlorophyll meter readings in leaves of eight tropical and subtropical fruit-tree species. J. Plant Physiol. 138:674-677.

Schepers, J.S., T.M. Blackmer, and D.D. Francis. 1998. Chlorophyll meter method for estimating nitrogen content in plant tissue, p. 129-135. In: Y.P. Kalra (ed.). Handbook of reference methods for plant analysis. CRC Press, Boca Raton, Fla.

Syvertsen, J.P. 1987. Nitrogen content and $\mathrm{CO}_{2}$ assimilation characteristics of Citrus leaves. HortScience 22:289-291.

Syvertsen, J.P. and M.L. Smith, Jr. 1984. Light acclimation in citrus leaves. I. Changes in physical characteristics, chlorophyll, and nitrogen content. J. Amer. Soc. Hort. Sci. 109:807-812.

Syvertsen, J.P., J. Lloyd, C. McConchie, P.E. Kriedemann, and G.D. Farquhar. 1995. On the relationship between leaf anatomy and $\mathrm{CO}_{2}$ diffusion through the mesophyll of hypostomatous leaves. Plant Cell Environ. 18:149-157.

Taiz, L. and E. Zeiger. 1991. Plant Physiology. Benjamin/Cummings Pub. Co., New York.

Terashima, I. and T. Saeki. 1983. Light environment within a leaf. Plant Cell Physiol. 24:1493-1501.

Turner, F.T. and M.F. Jund. 1991. Chlorophyll meter to predict nitrogen topdress requirement for semidwarf rice. Agron. J. 83:926-928.

Vogelmann, T.C. 1989. Penetration of light into plants. Photochem. Photobiol. 50:895-902.

Wellburn, A.R. 1994. The spectral determination of chlorophylls a and b, as well as carotenoids, using various solvents with spectrophotometers of different resolution. J. Plant Physiol. 144:307-313.

Whaley, E. 2001. Space tool fills universal void: Chlorophyll meter designed for satellite finds earthly uses. Resource Eng. Technol. Sustainable World 8(2):13-14.

Wood, C.W., P.W. Tracy, D.W. Reeves, and K.L. Edmisten. 1992. Determination of cotton nitrogen status with a hand-held chlorophyll meter. J. Plant Nutr. 15:1435-1448. 